\title{
WITNESS'S RIGHT TO COUNSEL IN STATE INVESTIGATIVE PROCEEDINGS
}

\section{$I_{N} 1957$ the Appellate Division of the New York Supreme Court}

ordered an investigation into allegedly improper practices by certain members of the New York state bar. ${ }^{1}$ One phase of the investigation consisted of a fact-finding "preliminary inquisition" at which subpoenaed witnesses were questioned before a Supreme Court judge, who was assisted by an attorney representing the Brooklyn Bar Association. ${ }^{2}$ For the protection of innocent parties, the judge was empowered to hold secret sessions and to exclude witnesses' counsel from the proceedings. ${ }^{3}$

Among the subpoenaed witnesses were certain private investigators who were suspected of misrepresenting their identity to obtain statements relevant to negligence cases. Though personally beyond the purpose of the investigation, they had been summoned to state whether any attorneys had collaborated with them in these activities. Shortly

${ }^{1}$ The Appellate Division acted pursuant to N.Y. JUd. LAW $\S 90$ (McKinney I948). The investigation was ordered in response to a petition from the Brooklyn Bar Association. By January 5, 1960, the investigation had resulted in the disbarment of eight attorneys, one year's suspension for three more, and judicial censure for another. N.Y. Times, Jan. 5, 1960, p. 27, col. 3 .

2 The inquiry was a quasi-administrative proceeding at which there were no parties and no charges. The presiding judge could make no adjudication. "[T] he result of the inquiry and investigation ... would be merely a report to the Appellate Division and recommendation as to future action, and would not be a final determination." Matter of M. Anonymous v. Arkwright, 5 App. Div. 2d 790, 791, 170 N.Y.S.2d 535, 537-38 (1958), motion for leave to appeal denied, 4 N.Y.2d 676 , 149 N.E.2d 538 (1958). See People ex rel. Karlin v. Culkm, 248 N.Y. 465, I62 N.E. 487 (rg28); Matter of S. Anonymous v. Arkwright, 5 App. Div. 2d 792, 170 N.Y.S.2d 538 (1958).

Ordinarily, under this statute, it is the duty of the district attorney, when designated by the Appellate Division, to prosecute all proceedings leading to disbarment of attorneys. But, in a county wholly included within a city or in a county of over 300,000 inhabitants, the presiding judge may appoint an attorney nominated by the local bar association to prosecute the proceedings. N.Y. JuD. LAW $\S 90(7)$ (McKinney 1948).

${ }^{3}$ N.Y. Jud. LAW $\S 90$ (10) (McKinney 1948), requires that the findings of the investigation be "private and confidential." It was within the presiding judge's discretion, under this mandate, to exclude witnesses' counsel from the inquiry. Matter of M. Anonymous v. Arkwright, supra note 2 ; S. Anonymous v. Arkwright, supra note 2. Gf., People ex rel. Keeler v. McDonald, 99 N.Y. 463 , 2 N.E. 615 (1885).

On the desirability of secrecy, Chief Judge Cardozo wrote, "The mere summons to appear at such a hearing and make report as to one's conduct may become a slur and a reproach .... The remedy is to make the inquisition a secret one in its preliminary stages." People ex rel. Karlin v. Culkin, 248 N.Y. 465,479 , I62 N.E. 487,492 (1928). 
after receiving subpoenas, they were warned by a member of the investigating staff that enough evidence had been found for a "prima facie case" against them, and that this evidence might be presented to the district attorney if they invoked the fifth amendment and refused to cooperate. ${ }^{4}$ At the inquiry, however, the presiding judge assured them that they had been called only as witnesses against the attorneys under investigation, not as persons for whom prosecution was contemplated. On this ground the judge invoked his power to bar their counsel from the proceedings, although he promised them that they could leave the hearing room at any time to consult their counsel. The witnesses thereupon refused to testify, claiming that their right to counsel as guaranteed by the fourteenth amendment was being abridged. They were convicted of contempt for their refusal to testify. ${ }^{5}$ The United States Supreme Court sustained the conviction in a five-to-four decision. ${ }^{0}$

Justice Harlan, speaking for the majority of the Court, held that the case was controlled by In re Groban, in which the Court ruled that the right to counsel does not extend to investigatory proceedings from which no adjudication of rights results. ${ }^{7}$ He cited analogically the .

"This information was imparted to appellants in an off-the-record conversation initiated by them in the foyer outside the hearing room. The unofficial warning apparently represented an attempt to dissuade appellants from any uncooperative action.

The right against self-incrimination was available to appellants under the New York Constitution. N.Y. Const. art. I, $\S 6$.

${ }^{5}$ Before the witnesses were convicted, their counsel was allowed to argue the contempt charge. It has been held unconstitutional summarily to convict witnesses for contempt at secret proceedings without allowing them benefit of counsel. In re Oliver, 333 U.S. 257 (1948).

${ }^{\circ}$ Anonymous Nos. 6 and 7 v. Baker, 360 U.S. 287 (1959). Actually the Supreme Court dismissed the appeal on a jurisdictional point because the constitutionality of the statute was never questioned in the state court. Then, however, the appeal was accepted as a petition for writ of certiorari, and the writ was granted.

Justice Black wrote a dissenting opinion in which he was joined by Chief Justice Warren and Justices Douglas and Brennan.

7352 U.S. 330 (1957). In this case, an Ohio statute permitted fire marshals to hold closed investigations of the causes of fires. In the course of one such investigation certain property owners were called to give information about a fire which had occurred on their premises. They refused to testify unless their counsel could be present. The fire marshal thereupon ordered them committed to jail until they were ready to cooperate. This action was upheld in the United States Supreme Court by a five to four margin. Justice Reed, joined by Justices Burton and Clark, wrote the majority opinion; Justices Frankfurter and Harlan concurred in an opinion by Justice Frankfurter. Justice Black wrote a dissenting opinion in which Chief Justice Warren and Justices Douglas and Brennan joined. The majority opinion by Justice Reed stressed that, "Appellants here are witnesses . . . A witness before a grand jury cannot insist, as a matter of constitutional right, on being represented by his counsel, nor can a witness before other investigatory bodies." Id. at 332-33. The fact that ". . evidence obtained may possibly 
established constitutionality of barring counsel from grand jury proceedings: $^{8}$ In his opinion, the warning given the appellants by the staff assistant was unauthorized and was outweighed by the judge's contrary assurances that prosecution was not contemplated for them. Moreover, he pointed out, in New York the appellants were sufficiently protected by the right against self-incrimination. ${ }^{9}$

Justice Black reaffirmed his vigorous dissent in the Groban case. The nonadjudicatory nature of the proceeding did not, in his opinion, alleviate the hardships imposed upon the appellants by denying them counsel. Furthermore, he said, the preservation of innocent reputations was hardly advanced by barring the appellants' counsel. He then concluded that no "judge ... . or any other government official . . . can consistently with due process compel persons to testify and perhaps to lay the groundwork for their later conviction of crime, in secret chambers, where counsel for the State can be present but where counsel for the suspect cannot."

If the proceeding in question had been technically a criminal trial, appellants would undoubtedly have been entitled to the assistance of their retained counsel. ${ }^{11}$ The problem, however, is whether the right

lay [appellants] ... open to criminal charges" did not entitle them to counsel. Id. at 333. Moreover, Justice Reed thought a "presumption of fair and orderly conduct by the state officials without coercion or distortion exists until challenged by facts to the contrary." Id. at 334 .

By the date of the instant case, two members of the Groban majority, Justices Reed and Burton, had left the Supreme Court. But Justices Whittaker and Stewart, who succeeded them, proved to be of the same bent as their predecessors on this question.

8 Gilmore v. United States, 129 F.2d 199 (roth Cir.), cert. denied, 3 I 7 U.S. 631 (1942); In re Black, 47 F.2d 542 (2d Cir. I93I). Cf., United States v. Scully, 225 F.2d I 3 (2d Cir.), cert. denied, 350 U.S. 897 (1955). See also, Orfield, The Federal Grand Jury, 22 F.R.D. 343, 431 (1959).

Justice Black, however, distinguishes the grand jury session from the type of proceeding here in question. He says of grand jurors: "They bring into the grand jury room the experience, knowledge and viewpoint of all sections of the community. They have no axes to grind and are not charged personally with the administration of the law .... It would be very difficult for officers of the state seriously to abuse or deceive a witness in the presence of the grand jury. Similarly the presence of the jurors offers a substantial safeguard against the officers' misrepresentation, unintentional or otherwise, of the witness' statements and conduct before the grand jury." In re Groban, supra note 7 , at 347 (dissenting opinion).

${ }^{\circ}$ N.Y. Const. art I, \$ 6 .

${ }^{10}$ Anonymous Nos, 6 and 7 v. Baker, 360 U.S. 287,299 (1959).

${ }^{11}$ Crooker v. California, 357 U.S. 433 (r958); Chandler v. Fretag, 348 U.S. 3 (1954); House v. Mayo, 324 U.S. 42 (1945). Powell v. Alabama, 287 U.S. 45, 69 (1932), contains the oft-quoted statement that an accused "requires the guiding hand of counsel at every step in the proceedings against him."

This same right is, of course, guaranteed in the federal courts by the sixth amendment. 
to counsel exists at such quasi-administrative proceedings as the one in question. A line of authority culminating with In re Groban and the instant case has recognized a distinction between administrative "hearings" and "investigations."12 A proceeding that normally results in a determination of rights after presentation of evidence by adversary parties is considered a hearing. ${ }^{13}$ An investigation, on the other hand, has no formal parties, and its only purpose is the discovery of information upon which to base later action. ${ }^{14}$ Obviously, the distinction can become a nice one. The parties to a hearing are assured extensive rights, including the right to counsel. ${ }^{15}$ But the witnesses at an investigation ostensibly have no rights at stake and can be denied the benefit of counsel. $^{16}$ In reality, every proceeding involves the rights of its participants to a greater or lesser extent; "adjudicative" and "administrative" are basically conclusory as to the need for counsel.

12 "Whatever the appropriate label, the kind of order that emerges from a hearing before a body with power to ordain is one that impinges upon legal rights in a very different way from the report of a commission which merely investigates and advises." Norwegian Nitrogen Prod. Co. v. United States, 288 U.S. 294, 318 (1932). See, e.g., Bowles v. Baer, 142 F.2d 787 (7th Cir. 1944); In re Securities \& Exch. Comm'n, 84 F.2d 316, 318 (2d Cir.), rev'd as moot sub nom., Bracken v. Securities \& Exch. Comm'n, 299 U.S. 504 (1936); Holt v. Raleigh City Bd. of Educ., 164 F. Supp. 853, 868 (E.D.N.C. $\times 958$ ), aff'd, 265 F.2d 95 (4th Cir.), cert. denied, 361 U.S. 818 (1959); Federal Trade Comm'n v. Scientific Living, Inc., r50 F. Supp. 495, 501 (M.D. Pa. x957). See generally, i Davis, Administrative LaW \& 8.10 (1958); Note, Representation by Counsel in Administrative Proceedings, 58 CoLUM. L. REv. 393 (1958).

${ }^{13}$ See, e.g., Holt v. Raleigh City Bd. of Educ., supra note 12 ; In re Securities \& Exch. Comm'n, supra note 12 .

${ }^{24}$ See, e.g., Bowles v. Baer, 142 F.2d 787 (7th Cir. 1944); In re Securities \& Exch. Comm'n, supra note I2.

${ }^{15}$ Note, Representation by Counsel in Administrative Proceedings, 58 Colum. L. REv. 393 (1958).

${ }^{16}$ United States v. Levine, 127 F. Supp. 651 (D. Mass. 1955); Bowles v. Baer, ${ }_{42}$ F.2d 787 ( 7 th Cir. 1944). Cf., United States ex rel. Bilokumsky v. Tod, 263 U.S. 149 (1923); Low Wah Suey v. Backus, 225 U.S. 460 (1912) (preliminary deportation proceedings); Niznik v. United States, 173 F.2d 328 (6th Cir.), cert. denied, 337 U.S. 925 (1949); United States v. Pitt, 144 F.2d I69 (3d Cir. 1944) (draft board proceedings); The Golden Sun, 30 F. Supp. 354 (S.D. Cal. 1939) (inquiry held by American consul preliminary to discharge of American seamen in foreign ports).

${ }^{27}$ Statutes have been enacted that guarantee counsel in certain proceedings, regardless of the investigative-administrative distinction. Section $6(2)$ of the Administrative Procedure Act provides that any person compelled to appear before a federal administrative agency may have counsel. Administrative Procedure Act $\S 6(a)$, 60 Stat. 240 (1946), 5 U.S.C. 1005 (a) (1958). For limitations thereon, see DAvis, op. cit. stupra note $12, \S 8.10$. A New York statute makes the same provision for many agencies of the state government. N.Y. Crvil RighTs § 73(3) (McKinney 1954). A bill to extend that proviso to proceedings like the instant one did not pass the New York State Legislature, however. 
The narrow adjudicative-investigative distinction may also be used to determine that point in the criminal-law process at which the right to counsel accrues. ${ }^{18}$ In most jurisdictions, there is usually no right to counsel during a police interrogation. ${ }^{19}$ Nor is the right usually available at a coroner's inquest, ${ }^{20}$ or a grand jury session, even when the witness's own indictment is under consideration. ${ }^{21}$ There is conflict as to whether the right is available for a preliminary hearing. ${ }^{22}$ On the other hand, counsel is generally allowed for the arraignment. ${ }^{23}$ Here, too, one proceeding may have as much effect upon the individual's rights as another proceeding, despite a different technical denomination.

Thus, it can be seen that such mechanical tests as the investigativeadjudicative distinction are altogether improper limitations on the constitutional right to counsel. Rather, as intimated by Justice Black, "the naked, stark issue" is whether the person demanding counsel is threatened with so great a harm that to deny him counsel cannot be fairly justified. ${ }^{24}$

This issue demands that careful attention be accorded the circumstances surrounding each case. The gravity of the threatened harm and the likelihood of its realization must be ascertained. The character of the proceeding must also be considered. Will the inquiry be conducted by an interested state official, such as a district attorney, or by a disinterested fact finder? Will it be secret or public, ${ }^{25}$ and will there

\footnotetext{
${ }^{18}$ See, e.g., People v. Coker, ro4 Cal. App. 2d 224, 23I P.2d 8I (195I); Roberts v. State, I45 Neb. 658, r7 N.W.2d 666 (r945).

See generally, BEANEY, THe Right to Counsel in AMERican Courts I26-29 (1955); Fellman, The Defendant's Rights I22-24 (1958); Fellman, The Right to Counsel under State Law, 1955 WIS. L. REv. 28I, 292-96. The Supreme Court cases most nearly on point are Crooker v. California, 357 U.S. 433 (1958), and Cicenia v. Lagay, 357 U.S. 504 (1958).

${ }^{12}$ See, e.g., Crooker v. California, 357 U.S. 433 (1958); Cicenia v. Lagay, 357 U.S. 504 (r958). $\left(\mathrm{Ig}_{4} \mathrm{I}^{2}\right.$.

${ }^{20}$ See, e.g., People v. Coker, stupra note 19 ; State v. Griffin, 98 S.C. I05, 82 S.E. 254

${ }^{21}$ Gilmore v. United States, r29 F.2d I99 (roth Cir.), cert. denied, 3 I7 U.S. 63 I (1942); In re Black, 47 F.2d 542 (2d Cir. r93I). Cf., United States v. Scully, 225 F.2d II3 (2d Cir.), cert. denied, 350 U.S. 897 ( 955 ).

${ }^{28}$ Many states deny counsel. See, e.g., Hawk v. State, ${ }_{5}$ I Neb. 717, 39 N.W.2d 56 (1949); Lyons v. State, 77 Okla. Crim. r97, 245, 138 P.2d 142, 167 (1943), aff'd, 322 U.S. 596 (r944). However, counsel is allowed in a significant number of jurisdictions. See, e.g., Wood v. United States, r28 F.2d 265, 277 (D.C. Cir. 1942); State v. Braasch, II9 Utah 450, 460, 229 P.2d 289, 293 (195 I), cert. denied, 342 U.S. 9 ro (1952).

${ }^{23}$ See, e.g., Winn v. State, 232 Ind. 70, 1 I I N.E.2d 653 (1953).

24 Anonymous Nos. 6 and 7 v. Baker, 360 U.S. 287, 299 (1959).

${ }^{25}$ Although secrecy and denial of counsel are separate issues, questions as to the
} 
be a reliable record? ${ }^{26}$ How formal will the proceeding be? A related question is the witness's need for professional assistance. A great deal will depend in this regard on his own level of sophistication and legal training as opposed to that of his interrogator. The complexity of the subject matter will also be relevant. Still another important question is whether the party asserting the right must contend with rebutting evidence or witnesses. If so, the skilled assistance of an attorney may be vital to the effective representation of his position.

Against these factors must be weighed the reasons for permitting interrogation without counsel. A witness is less likely to testify freely under the cautioning influence of his attorney. ${ }^{27}$ Moreover, a lawyer's efforts on behalf of his client will frequently tend to impede a proceeding. ${ }^{28}$ This is a particularly pertinent consideration where speed and spontaneity are important to effectiveness, as in a police interrogation. ${ }^{20}$ Furthermore, there may be unique reasons for denying counsel-for example, the need for secrecy in the instant situation.

Several alternatives can be adopted to mitigate the effects of denying counsel. Testimony improperly obtained from a witness without counsel can be made inadmissible in any subsequent prosecution of the witness. ${ }^{30}$ This may be poor consolation, however, when his testimony has enabled the authorities to gather enough independent evidence for a case against him. Moreover, it will usually be extremely difficult to prove that the officials in charge acted improperly. ${ }^{31}$ The right against self-incrimination can be made a more effective refuge if the interrogators will refrain from the various circumventing techniques currently

propriety of each will often be inextricably tied to the other. The dissenters' pervading concern with secrecy in In re Groban, 352 U.S. 330, 337 (1957), and the instant case, supra note 24 , at 298 , illustrates this.

In addition to its hearing on the right-to-counsel question, the investigative-adjudicative distinction may also determine whether the proceeding can be held in secret. Bowles v. Baer, 142 F.2d 787 (7th cir. 1944). See also, Davis, op. cit. supra note $12, \$ \$ 8.09$, 8.ro.

${ }^{20}$ Justice Black has pointed up the dangers of an inadequate record: "The officer's version frequently may reflect an inaccurate understanding of an accused's statements or, on occasion, may be deliberately distorted or falsified .... This is particularly true when the officer is accompanied by several of his assistants and they all vouch for his story." In re Groban, supra note 25, at 340-4 I (dissenting opinion).

${ }_{27}$ Fellman, The DefENdant's Rights 123 ( 1958 ).

${ }^{28}$ In re Groban, 352 U.S. 330,334 (1958). "In various proceedings . . . the presence of lawyers is deemed not conducive to the economical and thorough ascertainment of the facts." Id. at 336 (concurring opinion).

${ }^{20}$ Cicenia v. Lagay, 357 U.S. 504, 509 (195\$).

${ }^{30}$ In re Groban, 352 U.S. 330,334 (1957).

${ }^{31} I d$. at 343 n.1 6 (dissenting opinion). 
practiced. $^{32}$ Even so, few laymen are competent to master the intricacies that may be encountered in asserting that right. ${ }^{33}$ Moreover, unfavorable connotations now attach to pleading it. A better compromise is to allow some, but less than full, benefit of counsel, as in the instant case. The presiding officer can thus permit only so much participation by counsel as to him seems necessary. ${ }^{34}$ To satisfy the requirements of due process, however, the degree of assistance allowed must still be extensive enough to be considered fair when the conflicting factors have been balanced.

Analyzed along these lines, the instant case should not have been governed by In re Groban. ${ }^{35}$ Rather, the position taken by Justice Black seems preferable. Regardless of the inquiry's nature and immediate purposes, there existed a strong likelihood that the appellants' alleged activities would lead to criminal charges against them. Any information they might have provided about their activities would thus have carried "highly dangerous potentialities."36 Aside from the extraofficial uses to which the testimony might have been put, the Appellate Division could have later made it public, perhaps in connection with a disbarment proceeding. Furthermore, the inquiry was a relatively formal one in which the appellants were to be pitted, in effect, against an attorney from the state investigatory staff. In addition, the appellants did not know what evidence had been found against them and consequently could not know what questions would be asked them, nor the

\footnotetext{
${ }^{32}$ Pressures can be exerted to discourage an individual from raising his right against self-incrimination. Obviously, such physical and psychological threats as the one in the instant case are not without effect. If a public employee refuses to answer, his job may be imperilled. See Ratner, Consequences of Exercising the Privilege Against SelfIncrimination, 24 U. CHI. L. REv. 472, 493-5 II (1957). The most recent United States Supreme Court pronouncement is Nelson v. County of Los Angeles, $80 \mathrm{~S}$. Ct. 527 (1960). Unfavorable inferences of far reaching implication may be permitted. See Ratner, supra, at 472-93. See generally, Griswold, The FifTH AM ENDMENT Today 66-69 (1955).

Statutory immunity, of course, may offer only limited protection. Grant, Immunity from Compulsory Self-Incrimination in a Federal System of Government, 9 TEMP. L.Q. 57, 194 (1934), Knapp v. Schweitzer, 357 U.S. 37 r (1958).

${ }^{33}$ The average witness has little idea of how or when to raise the right. In addition, he cannot expect to cope with the nuances of the waiver doctrine and is hobbled by his fear of a contempt charge. In $r e$ Groban, 352 U.S. $330,345-46$ (1957) (dissenting opinion).

${ }^{34} I d$. at 349 (dissenting opinion).

${ }^{35}$ Justice Frankfurter said in the Groban case that differences in degree must be recognized. He thus implied that, whenever denying counsel subjects a party to imminent harm, due process has been violated. Id. at 337 (concurring opinion).

${ }^{36} 360$ U.S. at 299 (dissenting opinion).
} 
implications thereof. When the threat against raising the fifth amendment is added, their need for counsel becomes acute. Neither the presence of the presumably disinterested judge nor his assurances that no prosecution was contemplated for them could outweigh these factors.

The promise of periodic consultation with their counsel held only limited value for the appellants. Without legal assistance in the hearing room they could have easily made a misleading or damaging statement, especially in reply to some seemingly innocuous question. Moreover, the fact that they might have left the hearing room to consult their counsel was of limited value because their counsel would have had to rely upon the appellants' nonprofessional recounting of their situation at that point of the proceeding in formulating their advice.

There were no compelling reasons for denying counsel to the appellants. It seems unlikely that the participation of their counsel would have impeded the inquiry any more than would periodic interruptions for outside consultation. ${ }^{37}$ Nor would the appellants' counsel, charged with the confidence of their clients, have endangered the confidential nature of the inquiry. Although appellants might have testified more freely in the absence of their counsel, this is one of the dangers at which the right to counsel is aimed and should be relied on as a ground for denying counsel only in case of compelling public necessity.

\footnotetext{
${ }^{37}$ This assumes, of course, that denying appellants the privilege of ever consulting their counsel would have been unconstitutional, or at least an abuse of the presiding judge's discretion.
} 